\title{
Observing the rising and falling of water level in Mosul Dam Lake using remote sensing data and Geographical Information System
}

\author{
K.A.Ahmed \\ Assistant Lecturer
}

\author{
R.G. Thanoon
}

Lecturer

\section{A.R. Abdurrahman}

Assistant Lecturer

\section{ABSTRACT}

Multi temporal Landsat ETM+ satellite images for the period (1986 to 2009) are used to determine the boundary of Mosul Dam Lake. Digital Image processing (Enhancement, Image Fusion and classification) applied for the input data. The output images showed the values of surface area in $\mathrm{Km}^{2}$. In order to extract the level of water a digital elevation model was combined with the output images.

The (Elevation - Area - Volume) curve for Mosul Dam Lake (which depended on field measurements) used to compare the values of water level of the lake that extracted from the satellite images with digital elevation model and that one plotted on the curve. The results of this study showed an agreeable convergence between them.

Keyword: Mosul dam, Remote sensing, GIS.

$$
\begin{aligned}
& \text { مراقبة ارتفاع وانخفاض منسوب المياه في بحيرة سد الموصل باستخدام بيانات }
\end{aligned}
$$

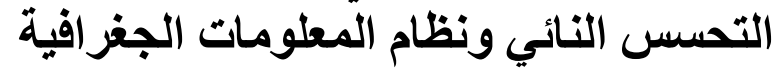

$$
\begin{aligned}
& \text { عبدالرحمن رمزي عبدالرحمن } \\
& \text { ريان غازي ذنون } \\
& \text { خنساء عبدالاله احمد } \\
& \text { مدرس مساعد } \\
& \text { مدرس } \\
& \text { مدرس مساءد }
\end{aligned}
$$

الملخص

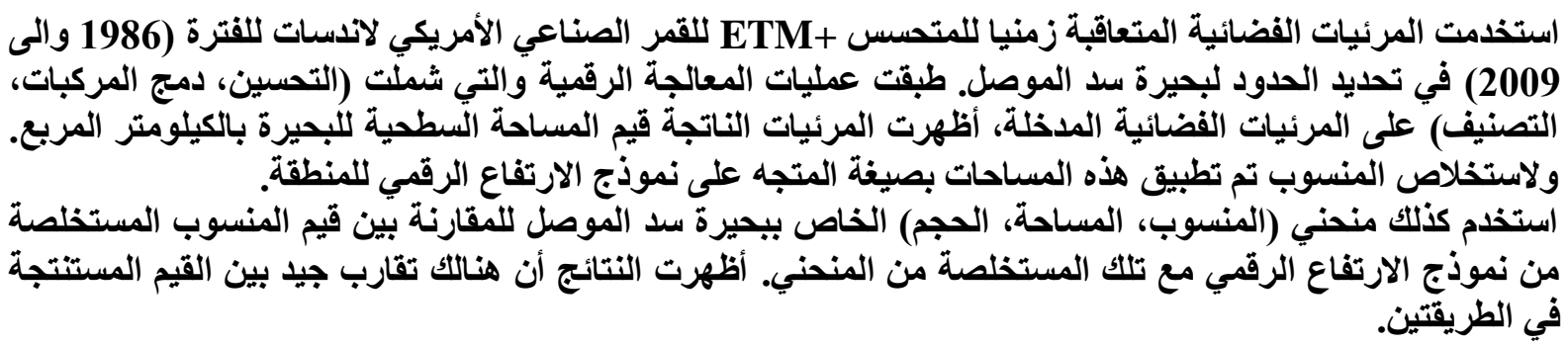

الكلمات الدالة: سد الموصل، التحسس النائي، نظام المعلومات الجغرافية. 


\section{Introduction:}

Ground surveys are complicated, expensive, especially when the studied areas were very large and contain obstacles such as buildings and other installations. The topographical nature of the area is considered as one of the most important factors that could limit the operations of ground surveys like the presence of hills and valleys. Satellite images, when used properly, will provide some clear information on areas without resorting to fieldwork, which was impossible in some places.

The satellite images became an effective tool for many practical and scientific studies for its comprehensive vision of manifestations of the Earth's surface. It can be used to show locations, distances, and the size of areas, display geographic relationships, differences, clusters and patterns, in addition to the possibility of extracting a lot of information through the geographical information system (GIS) software and the digital image processing techniques [4].

\section{Study area:}

In the present study, the satellite images used to extract the surface area of Mosul dam lake which was a reservoir in the course of the Tigris river formed as a result of the construction of the Mosul Dam. It is located between latitudes $36^{\circ} 35^{\prime \prime}$ to $36^{\circ} 55^{\prime \prime} \mathrm{N}$ and Longitudes $42^{\circ} 24 "$ to $43^{\circ} \mathrm{E}$. in the northern Iraq approximately $50 \mathrm{~km}$ northwest of Mosul city and $80 \mathrm{~km}$ from Syria and Turkey as in figure(1). The dam was completed in June 1984 with the initial filling of the reservoir during the following spring. The majority of the water was entering the reservoir from Turkey. The dam functions were for flood control, irrigation and power supply, providing Mosul with the majority of its power. The active storage in the reservoir is over $8.1 * 10^{9}$ $\mathrm{m}^{3}$ and the total storage at maximum retention is 11.1 billion $\mathrm{m}^{3}$.

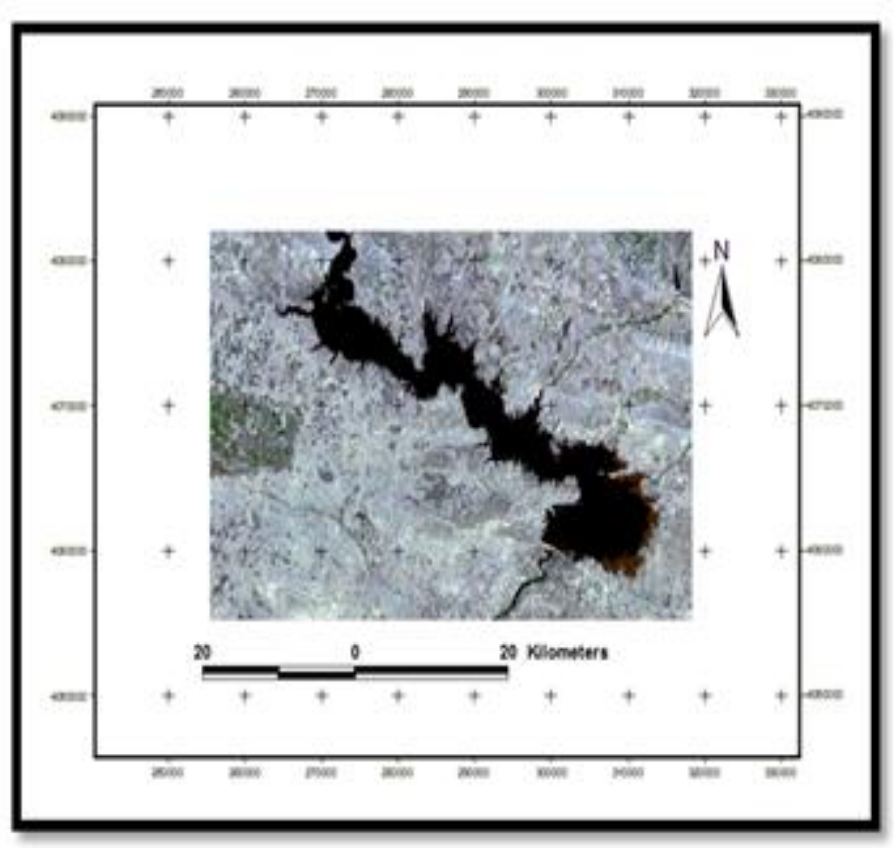

Figure 1. The study area

The maximum operating level is $330 \mathrm{~m}$, the maximum water level was $335 \mathrm{~m}$ and the bottom of reservoir basin was approximately $250 \mathrm{~m}$. The dam played a main role in the local and national economy that was the reason why the water levels were accurately controlled. the data used in table 1. Showed the properties of multi temporal Landsat ETM+ images used in the current study [8].

Spatial resolution is the real size of an image pixel, an increase in spatial resolution corresponds to an increase in the ability to distinguish one feature from another.

While the spectral resolution, is the size and number of wavelengths intervals, or divisions of the spectrum that a system is able to detect. Fine spectral resolution generally means that it is possible to resolve a large number of similar sized wavelengths, as well as to detect radiation from a variety of regions of the spectrum. [9].The relationship between reservoir volume - water level - reservoir surface area shown in figure (2) also used in the analysis 
Table (1) the data used in the study

\begin{tabular}{|c|c|c|c|}
\hline Date & Band No. & Spatial resolution $(\mathrm{m})$ & Spectral resolution $(\mu \mathrm{m})$ \\
\hline 1986 & 2 & $28.5^{*} 28.5$ & $0.525-0.605$ \\
\hline 1986 & 3 & $28.5^{*} 28.5$ & $0.630-0.609$ \\
\hline 1986 & 4 & $28.5^{*} 28.5$ & $0.750-2.35$ \\
\hline 2001 & 2 & $28.5 * 28.5$ & $0.525-0.605$ \\
\hline 2001 & 4 & $28.5 * 28.5$ & $0.750-2.35$ \\
\hline 2001 & 7 & $28.5 * 28.5$ & $2.08-2.35$ \\
\hline 2002 & 2 & $28.5 * 28.5$ & $0.525-0.605$ \\
\hline 2002 & 4 & $28.5 * 28.5$ & $0.750-2.35$ \\
\hline 2002 & 7 & $28.5 * 28.5$ & $2.08-2.35$ \\
\hline 2003 & 2 & $28.5 * 28.5$ & $0.525-0.605$ \\
\hline 2003 & 4 & $28.5 * 28.5$ & $0.750-2.35$ \\
\hline 2003 & 7 & $28.5^{*} 28.5$ & $2.08-2.35$ \\
\hline 2004 & 2 & $28.5 * 28.5$ & $0.525-0.605$ \\
\hline 2004 & 4 & $28.5^{*} 28.5$ & $0.750-2.35$ \\
\hline 2004 & 7 & $28.5 * 28.5$ & $2.08-2.35$ \\
\hline 2009 & 2 & $28.5^{*} 28.5$ & $0.525-0.605$ \\
\hline 2009 & 4 & $28.5 * 28.5$ & $0.750-2.35$ \\
\hline 2009 & 7 & $28.5^{*} 28.5$ & $2.08-2.35$ \\
\hline
\end{tabular}

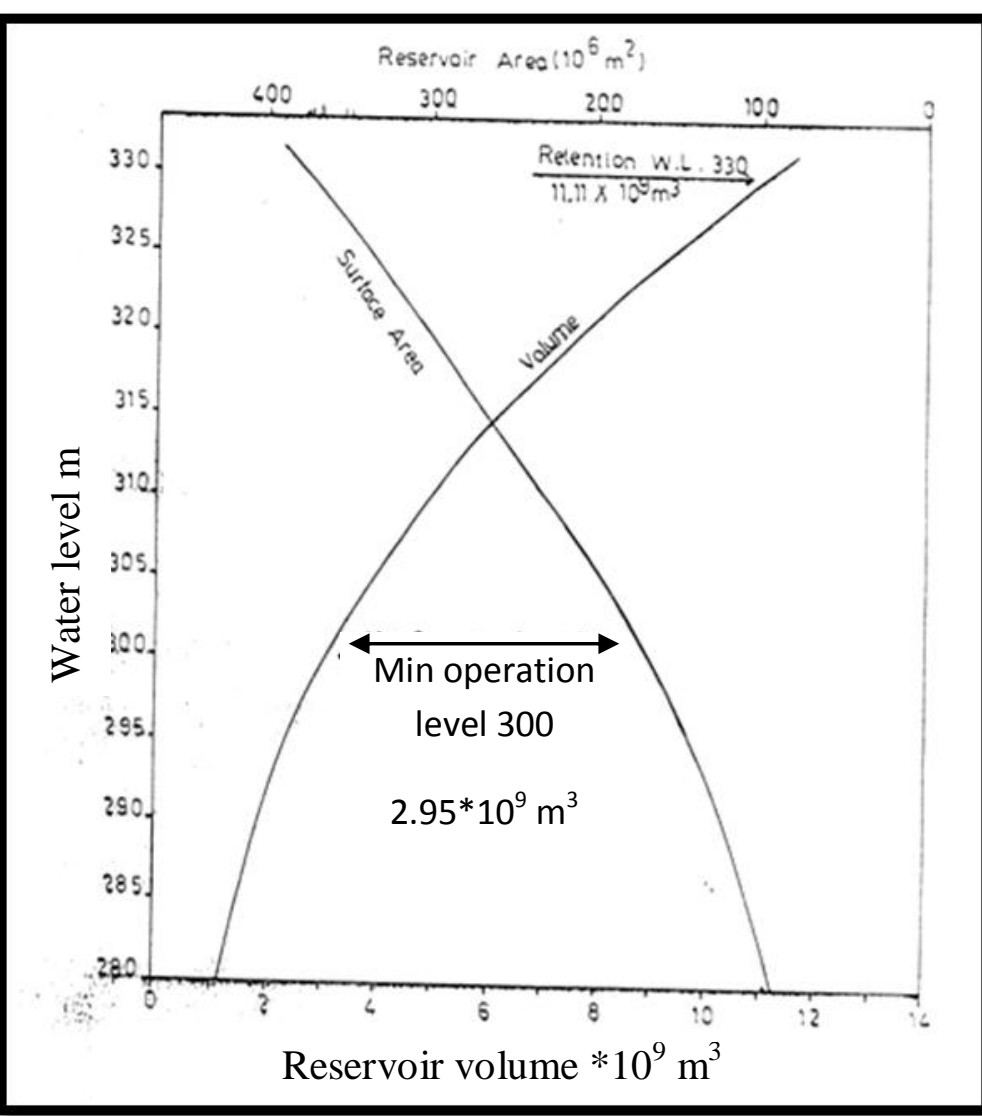

Figure 2. Elevation -Area-Volume curve for mosul dam lake 


\section{The Research Methodology}

The Flowchart shows in figure (3), designed to extract the elevation of water in any lake using the satellite images and Geographic information system (GIS), they consist of a several stages. In order to run the flowchart (ERDAS). Imagine 9.1 software adopted in the initial stages, (Images subset, Digital image processing). ArcView GIS 3.3 software used for victimization the images and Global Mapper v.11 software for water level extraction from the Digital elevation model (DEM). The digital elevation model (DEM) for Mosul dam lake area used as elevation reference for study captured and generated from Shuttle Radar Topography Mission (SRTM) with 30m resolution from USGS. Figure (4).

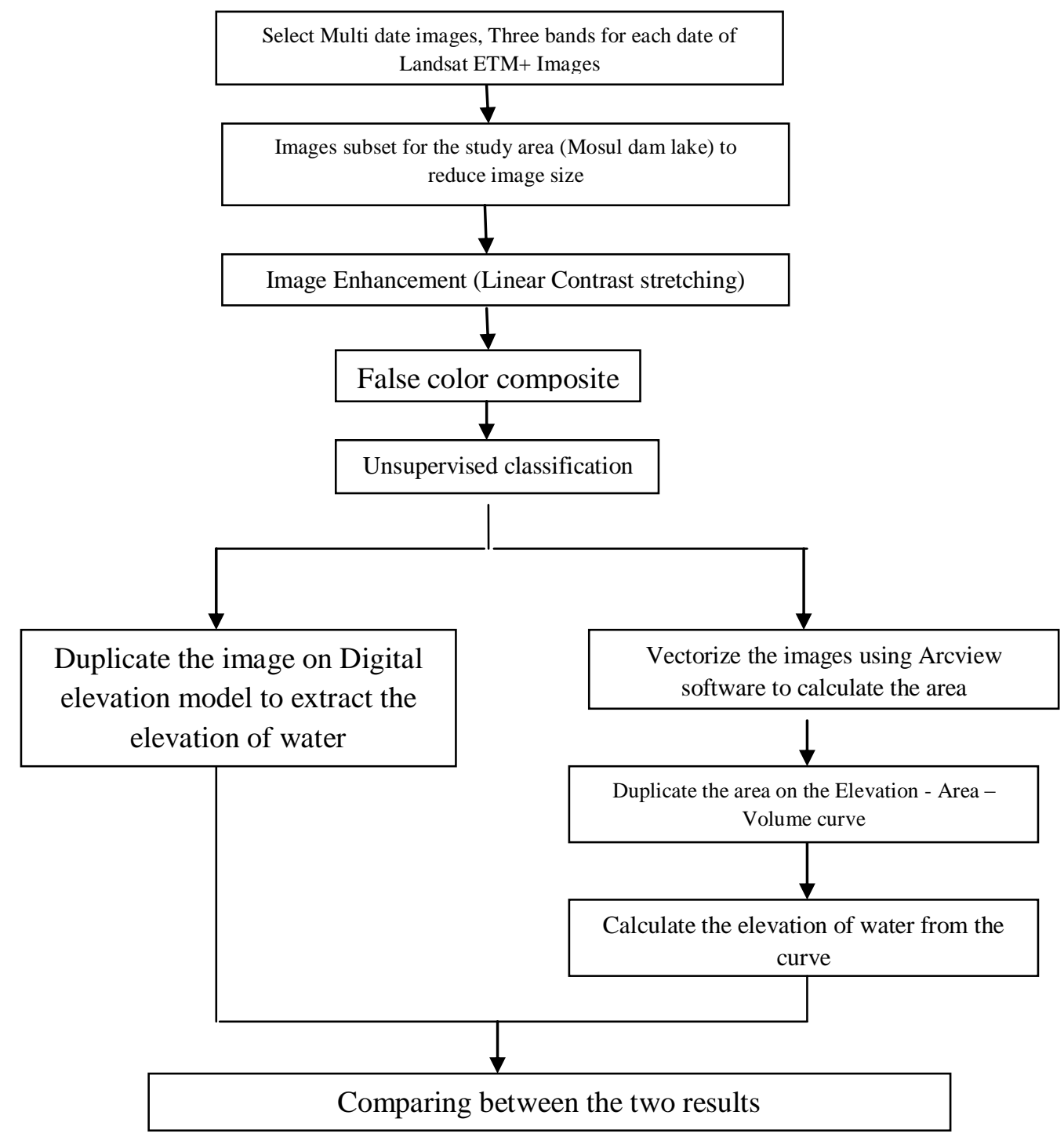

Figure 3. the research flowchart 


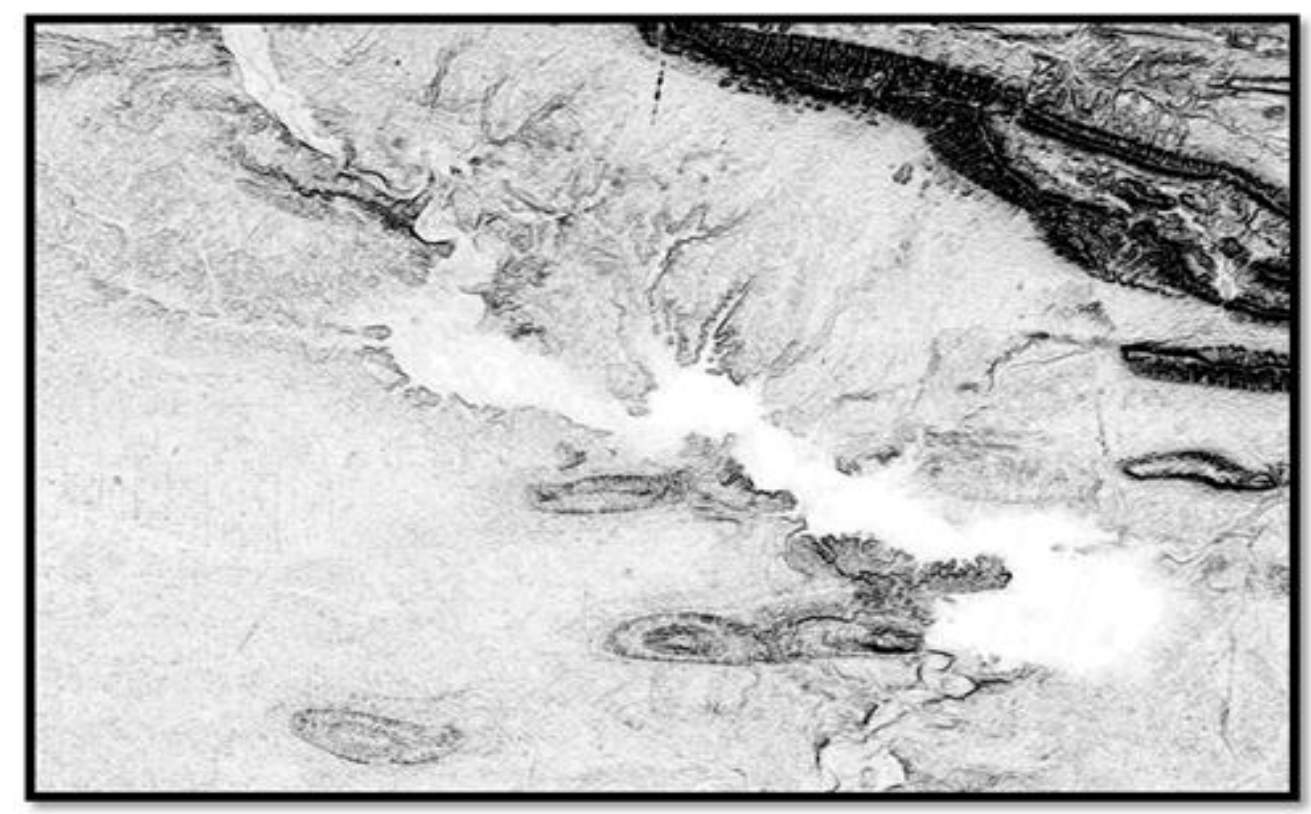

Figure 4. Digital Elevation Model for mosul dam lake area

\section{Digital Image Processing}

a-Image enhancement (Linear contrast stretching): In this study the linear stretch applied to increase the contrast and to detect the borders of lake and separate the water from the land before the false color composite process. An accurate visual interpretation may require modification of the output brightness of a pixel in an effort to improve image quality. Contrast stretching takes an image with clustered intensity values and stretches its values linearly over the 0-255 range.

Contrast stretching allocates the minimum and maximum input values to 0 and 255 , respectively. The process assigns a gray level 0 to a selected low DN value (DN=Digital Number), chosen by the user. All DNs smaller than this value are assigned 0 as well, grouping the low input values together. Gray level 255 is similarly assigned to a selected high DN value and all higher DN values. Intermediate gray levels are assigned to intermediate DN values proportionally. The resulting graph looks like a straight line while the corresponding histogram will distribute values across the range, leaving an increase to the image contrast. [7], [9].

b- Color composite: when dealing with a multi-band image, any combination of three bands used as input to the RGB (Red, Green, Blue) channels. The choice made based on application of the image data [1]. The best FCC (false color composite) depends on the purpose of the study. From several FCC produced for visual interpretation the best combination was 742 (RGB). This band combination used for an images exclusion except the image of 1986 were the bands 4,3,2 were used, because the band 7 for 1986 was not available. The water will be dark blue because of the high reflectance of water in band 2. Figure (5). 


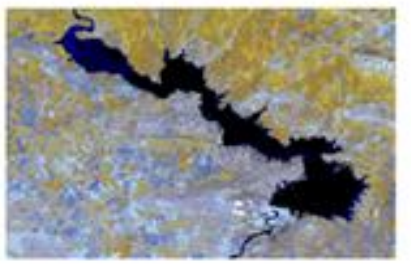

1986

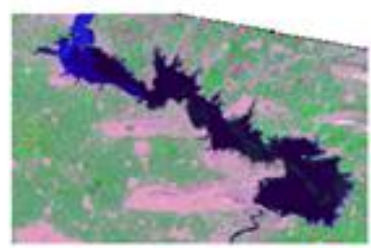

2003

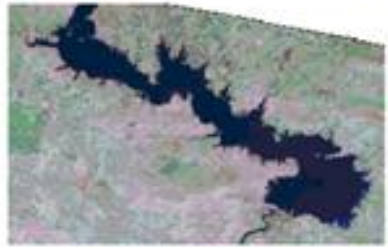

2001

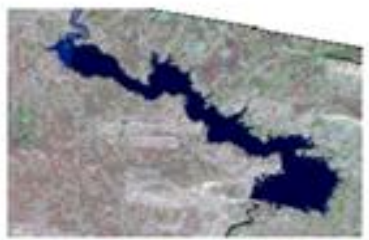

2004

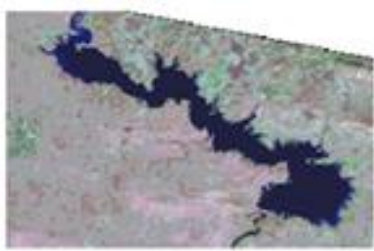

2002

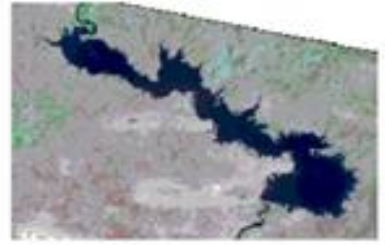

2009

Figure 5. The false color composite images

c- Classification: There are two main types of classification, the first one defined as the supervised classification, which was taking a samples represent the training area and then compared the vector patterns of these samples. The other type was the unsupervised classification, which a divided vector pattern was based on some degree cluster on the multidimensional space without previously specifying of the samples [5]. Supervised classification requires knowledge of the area at hand, in the current study our knowledge is not sufficient enough to use it and it is not important to classify the total classes in the image, just we need to detect the water class boundaries therefore the unsupervised classification was used. Figure (6).

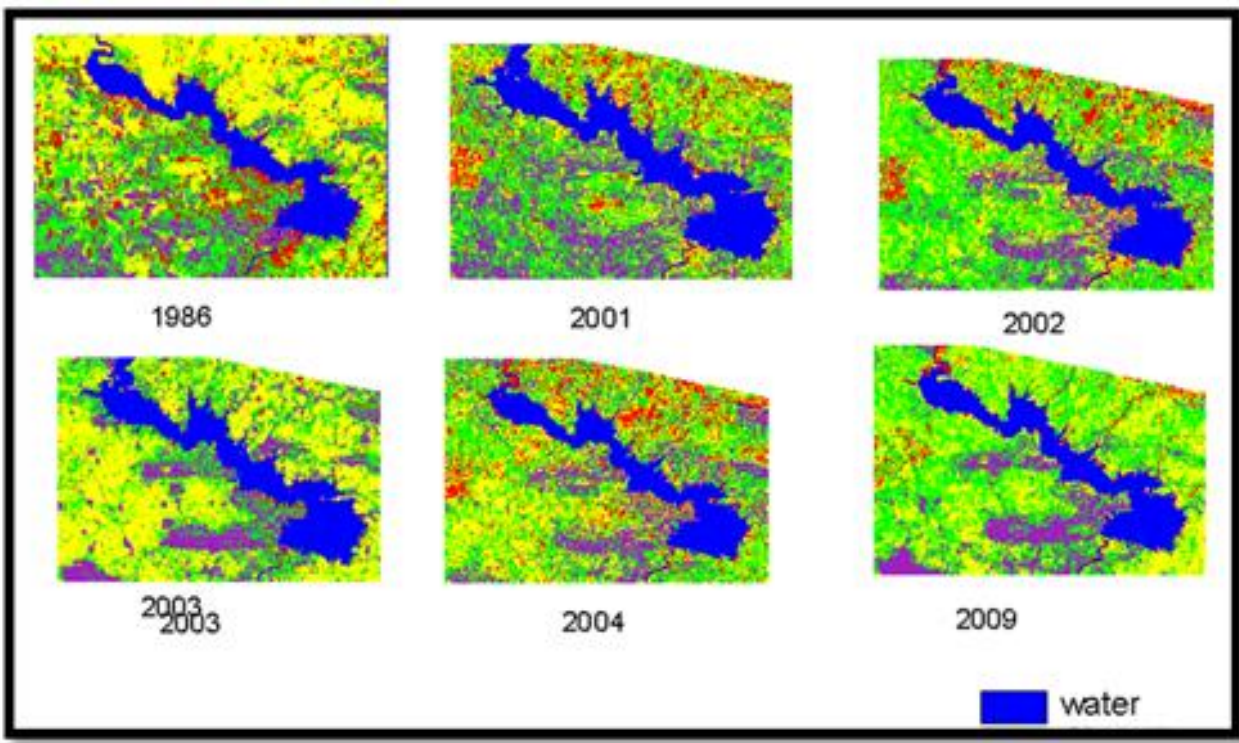

Figure 6. The classified images 


\section{Geographic Information System (GIS):}

Geographical Information System (GIS) can be defined as automated systems for the capture, storage, retrieval, analysis, and display of spatial data [2] , Geographic Information System (GIS)-based maps provide a flexible and efficient way to analyze and display spatial information. The strength of a GIS system is that data from various sources can be collected in local or remotely accessed data bases, which can be easily maintained and updated-GIS maps support optimal analysis, especially in hydrologic studies at different scales [3]. In this study ArcView GIS 3.3 software used for vectorizing the classified images and calculate the polygon area of Mosul Dam Lake or water class at different times, figure (7), then applying this area on Elevation -Area-Volume curve to extract the water level at that time. Global Mapper 11 software used to generate the contour map in $1.0 \mathrm{~m}$ contour interval from digital elevation model and extract the water level from it. Figure (8).

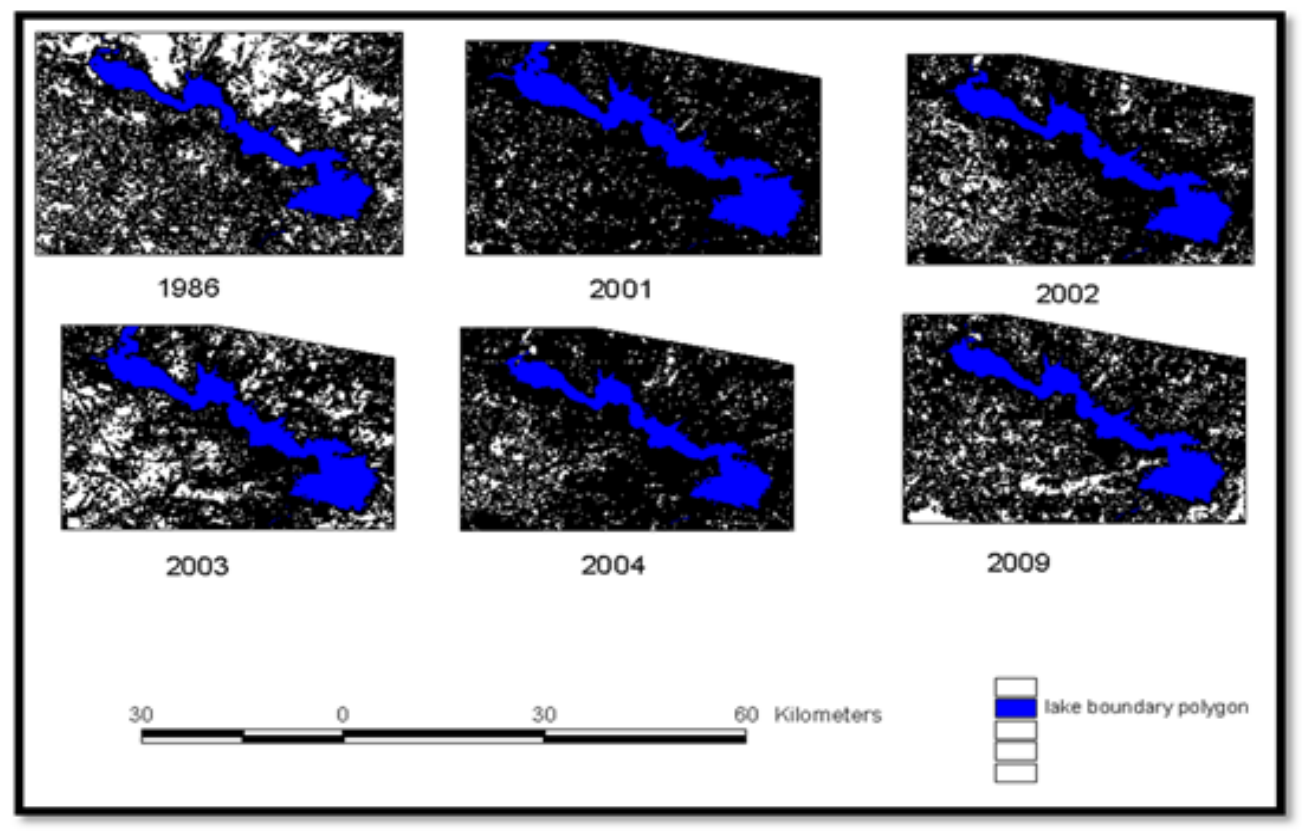

Figure 7. The vectorized images

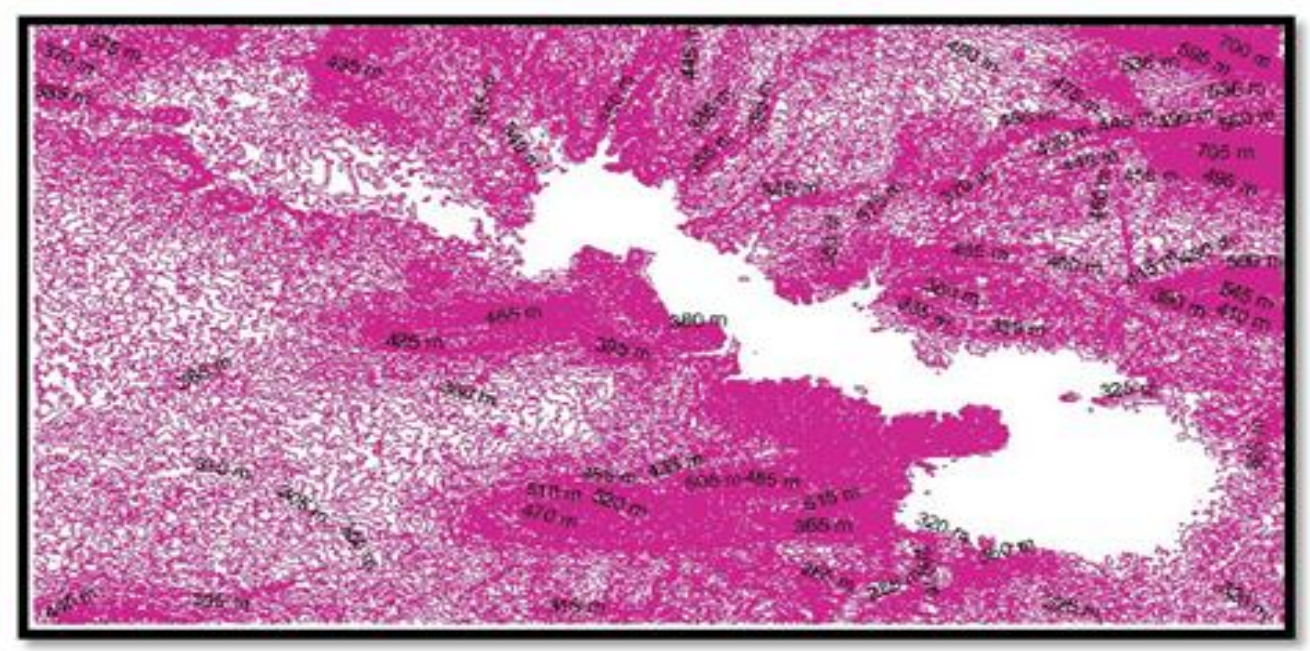

Figure 8. Contour map for the study area 


\section{Discussion:}

The major goal of this study was to develop a methodology for producing remote sensing data in water reservoirs studying using digital image processing techniques and GIS with the aid of field measurements from the results shown in table 2.

Table 2. results of the water levels from the curve and DEM.

\begin{tabular}{|c|c|c|c|}
\hline YEAR & $\begin{array}{c}\text { Surface area from } \\
\text { vectorize Images } \mathrm{m} 2\end{array}$ & $\begin{array}{c}\text { Elevation of water } \\
\text { from curve }\end{array}$ & $\begin{array}{c}\text { Elevation of water } \\
\text { from DEM }\end{array}$ \\
\hline 1986 & 338565712 & 317 & 316 \\
\hline 2001 & 346785264 & 323 & 322 \\
\hline 2002 & 249736821 & 314 & 316 \\
\hline 2003 & 292723528 & 315 & 314 \\
\hline 2004 & 229264872 & 308 & 315 \\
\hline 2009 & 243248568 & 312 & \\
\hline
\end{tabular}

The difference in the results shown in figure (9) that, the spatial resolution of the DEM is $30 \mathrm{~m}$ and the objective of the study required a resolution of $1 \mathrm{~m}$ to extract the water level. To generate a contour map of $1 \mathrm{~m}$, interpolation process was occurred between the contour lines and that is the reason why there is a little variance between the results from the DEM. The results from the curve were more conformable to the fact because the curve depended on field measurements and accredited in mosul reservoir.

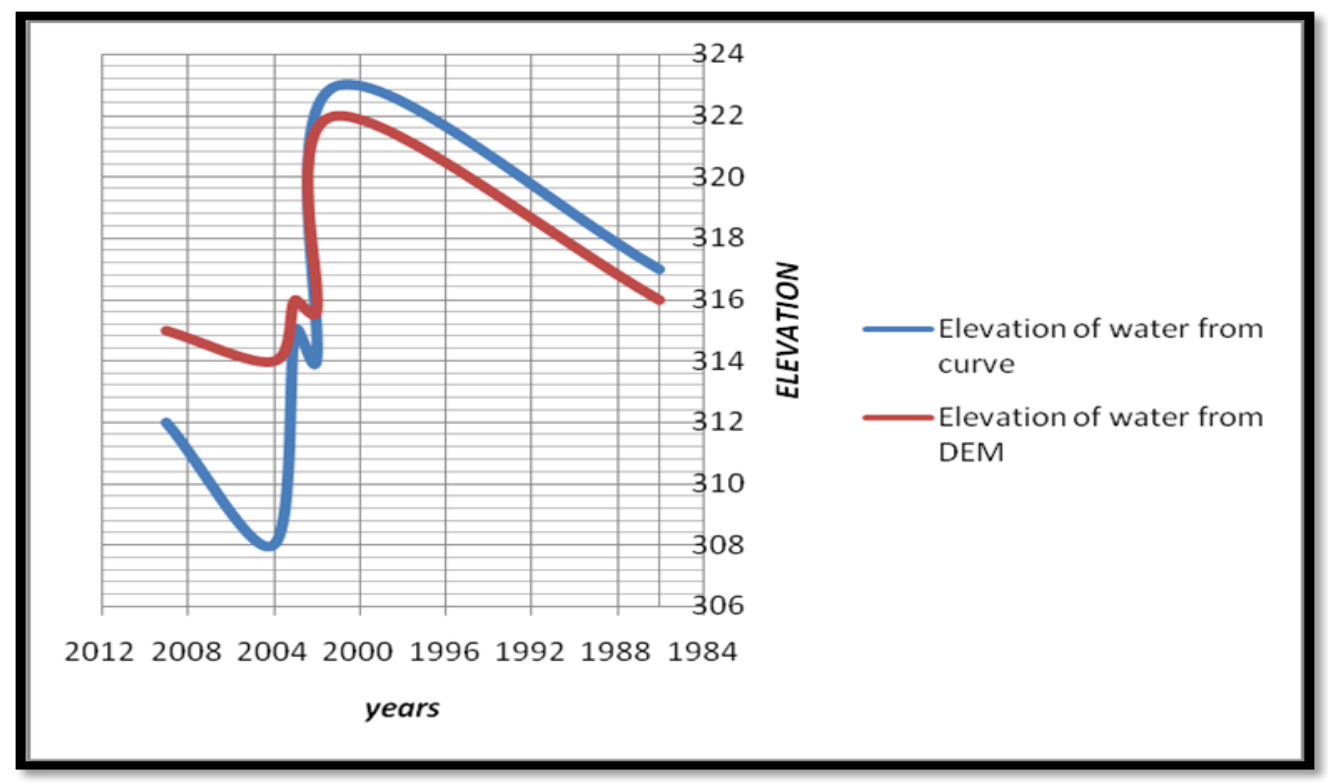

Figure (9) The comparison between the elevation of water from the curve and from the DEM 


\section{References :}

1. Bakker, w.h. and others,2004; "Principles of Remote Sensing", An introductory textbook, The International Institute for Geo-Information Science and Earth Observation (ITC), Hengelosestraat 99, P.O. Box 6, 7500 AA Enschede, The Netherlands.

2. Clarke, K. C., 1999; "Getting Started with Geographic Information Systems", 2nd edition, Prentice-Hall, Inc., 338p.

3. Consulting office, 2008; "Geographic Information systems", Remote sensing and ERDAS program (Advanced course), Syria-Damascus.

4. Kumar, M., 2008; "Digital image processing, photogrammetry and remote sensing division". Indian institute of remote sensing, Dehra Dun, pp81-108, Available at: www.wamis.org/agm/, accessed at: 28/ May/2008.

5. Lillesand , T.M. and Kiefer, R.W., 1994; "Remote sensing and image interpretation", 2 nd Ed. John Willey and Sons incop. , New York, 721 p.

6. Mather, P.M., 1987, "Computer processing of remotely sensed images", an international, John Wiley and Sons. 212p.

7. Richards,J.A. and Xiuping Jia,2006; "Remote Sensing Digital Image Analysis", 4th Ed. Sipringer-Verlag Berlin Heidelberg, Germany, 86p.

8. Sabins, JR.F. 1987; "Remote sensing : Principles and Interpretation", Freeman and Sons Co. , san Frarancisco , U.S.A. , 426 p.

9. Walsh, michael.J, 2003; "Remote sensing Engineering and Design", Engineering manual; US Army Crops of Engineers., 5-12p. 